have. We have heard, for instance, that a large number have been captured alive in the city of Calgary. We have heard, also, of many newspaper articles describing the demise of a lynx. We would like to collect all the informaticn we can on the Lynx invasion, so please send your records and have other interested people send their records to the Blue Jay editors, Box 1121, Regina. Our objectives are twcfold: to record the behaviour of this interesting animal, even under these unusual circumstances, and to document its occurrence, in order' to record permanently this astonishing forced movement of a wildlife species. Fifty years from ncw this information will be extremely interesting and valuable. The November, 1963, issue of North Dakota Outdoors, official publication of the State Game and Fish Department of that state, gives a fine report of the situation in that area in an article entitled "The Lynx Explosion".

It is unfortunate that the Wildlife Branch of the Saskatchewan Department of Natural Resources and the Saskatchewan Museum of Natural Histcry are not in a position to properly document, study, and report to the public such widespread and interesting wildlife phenomena. It has been explained that they do not have the time or resources to do this. We should therefore urge our legislators to provide the additional staff where needed in these agencies in order to ensure that proper attention is paid to wildlife on our behalf, on the public's behalf, and on the behalf of wildlife itself.-Blue Jay Editors.

\title{
Further Comments on Whistling Snowshoe Rabbits
}

by Helge S. Abrahamson, Sylvan Lake, Alberta

In the September, 1963, issue of the Blue Jay there is an interesting article by R. R. Hooper: "Saw-whet Owl-the case of the whistling rabbit." Hooper states that in the Punnichy district of Saskatchewan some Indians believe that the Snowshoe Rabbit or Varying Hare is the source of a peculiar whistling sound heard at night. Hooper identifies this instead as the call of the little owl called the Saw-whet Owl.

I have lived all my life in the Sylvan Lake district of Alberta and have observed Snowshoe Rabbits on many occasions. My house is lccated in a heavily wooded area of pcplar trees where these rabbits are very abundant. Many times upon hearing the whistling I have slowly edged toward the apparent source of the sound and with the aid of a powerful flashlight have found a rabbit. When I stcod still for some length of time the rabbit resumed its whistling, and was then only about 40 feet away from me. When I turned my flashlight upon it once more, it quickly stood up cn its hind legs, ceased whistling, turned around, then quickly moved away some distance before resuming its whistling act.
In the 1930's this area contained a few of the now scarce Saw-whet Owls which also give a whistling call. However, the rabbit's whistling is much more highly pitched and can readily be traced to its source whereas the call of the owl often seems to be coming frcm a distant point.

The call of the Saw-whet Owl is usually heard in the night frcm February to April. The rabbit's whistle is usually heard in the night, but often thrcughout the day, starting early in March and continuing until early June. I believe that these whistling sounds are the respective mating calls of the Saw-whet Owl and the Snowshoe Rabbit.

\section{BOOKS WANTED}

We buy books on birds, animals, amphibians, botany, wild flowers, mosses, rungi and related material. Send list for offer, we pay shipping.

Seven Seas Book Service

Box 15, Station "J" Toronto 6, Ontario 